\title{
Kansalaistieteellä viheliäisten ongelmien kimppuun
}

\author{
4 \\ Kansalaistiedettä ja vapaata sivistystyötä yhdistää \\ kansalaisten toiminta yhteisten päämäärien \\ hyväksi. Kansalaistieteellä on mahdollisuuksia tukea \\ aikuiskasvatustieteen tutkimusta.
}

\begin{abstract}
"KANSALAISTIETEEN KUTSU" -katsauksessaan Anja Heikkinen ja Jenni Pätäri lähestyvät kansalaistieteen käsitettä kriittisesti. He liikkuvat kansalaisuuden ja vapaan sivistystyön tieteellistämisen ja historiallisen rakentumisen sekä aikuiskasvatustieteen muutoksen kentällä. 'Kansalaistieteessä' maallikkotutkijat järjestelmällisesti edistävät tieteellistä tutkimusta keräämällä uutta aineistoa ja syventämällä jo olemassa olevaa tietoa. Siinä kansalaisen omaehtoinen aktiivisuus yhdistyy tutkimuksen edistämiseen.
\end{abstract}

TIEDE ON SIVISTYKSEN hyvä kumppani: kansalaiset suhtautuvat tieteeseen ja tieteellis-tekniseen kehitykseen myönteisesti. Joka kolmas vuosi julkaistava Tiedebarometri (2019) selvittää, onko tiedeyhteisö kansalaisten mielestä osaavaa sekä mikä asema tie- teellä ja tutkimuksella ylipäätänsä on kansalaisten arvostuksissa ja asenteissa. Vuoden 2019 barometrin mukaan kansalaiset luottavat tiedeinstituutioiden autonomisiin huippututkijoiden verkostoihin ja mediassa näkyvästi esillä oleviin tieteenaloihin. Kansalaistieteestä sen sijaan haetaan apua kansalaisten heikkoon tieteelliseen lukutaitoon, ja sillä halutaan tukea koulutusjärjestelmän puutteellisuuksia. Suomen peruskoulun laskevat PISA-tulokset luonnontieteessä ja matematiikassa, erityisesti poikien osalta, ovat tekijöitä, johon kansalaistieteen digitaalisella kehityksellä pyritään vaikuttamaan (Kirjavainen \& Pulkkinen 2017).

Covid-19-pandemia avasi tiedettä ja toi erityisesti luonnontieteellisen tutkimuksen merkityksen lähelle jokaista kansalaista. Pandemia räjähti käsiin, ja pelastus 


\section{VAPAA SIVISTYSTYÖ}

\section{ON REVITTY PALASIKSI}

\section{PALVELEMAAN}

\section{KANSALAISYHTEISKUNNASSA}

KULLOINKIN T $\ddot{A} R K E \ddot{A} N \ddot{A}$

PIDETTY $\ddot{A}$ TEHT $\ddot{A} \ddot{A A ̈}$.

löytyi tieteestä: rokotteen kehittäminen vakavaa tautia vastaan sekä sen mahdollisimman nopea testaus, valmistus ja käyttöönotto. Kun riittävän moni kansalainen olisi rokotettu, tauti ei pääsisi leviämään. Joulukuussa 2020, kun pandemian puhkeamisesta oli alle vuosi, testausvaiheessa ympäri maailmaa oli 54 erilaista rokotetta ja testauksen kliinisessä tutkimusvaiheessa oli 12 rokotetta. Lääkevalmistajista Pfizer/BioNTech ja Moderna ilmoittivat, että niiden rokotteet estävät noin 95 prosentin varmuudella Covid-19-taudin (Jong 2020).

Kun Tiedebarometri vuonna 2019, juuri ennen pandemian puhkeamista, kartoitti kansalaisten suhtautumista Suomessa annettaviin rokotteisiin, 95 prosenttia vastaajista piti rokotteita turvallisina ja tehokkaina. Samaan aikaan kansalaisten mielipiteet hajaantuivat: 32 prosenttia uskoi niiden haittavaikutuksiin ja 39 prosenttia piti niitä vaarallisina. Vähemmän koulutetut ja ikääntyneet kansalaiset kokivat, että rokotusten vaaroista ja haittavaikutuksista puhuttiin liian vähän.

Tiedebarometrin hypoteettinen kysymys kansalaisen asennoitumisesta rokotteeseen on nyt realisoitunut, ja jokainen ihminen on vakuutettava rokotuksen hyödyllisyydestä. Olisiko kansalaistieteellä ja vapaalla sivistystyöllä yhteinen sivistyksellinen intressi välittää ruohonjuuritason tieteellistä tietoa suurelle yleisölle rokotteiden merkityksestä ja vaikutuksesta? Voisiko kansalaisten tuki aktiivisessa tieteellisessä tietojen keruussa yli tieteenalojen välisten rajojen jarruttaa pandemian leviämistä?

VAPAALLA SIVISTYSTYÖLLÄ ja kansalaistieteellä on yhteisiä pyrkimyksiä: kansalaisten toiminta yhteisten päämäärien hyväksi (Koski 2006, 59; Tuomaa- la 2004, 63), objektiivinen tiedon muodostuminen poliittisen propagandan sijaan (Ollila 1993, 29-48), yhteiskunnallisesti vapaiden ja kansanvaltaisten kansalaisten kasvattaminen ja kansan pitäminen yhtenäisenä sivistyksen keinoin (Apo 1998, 83-128; Tuomaala 2004, 64-68; Lang 2011, 19-22).

Vaikka tieteellisen tutkimuksen on oltava tutkimusjohdettua, kansalaistiede tarjoaa oivan mahdollisuuden liittää tutkimus yhteiskuntaelämän kokonaisuuteen (vrt. Castren 1924). 2000-luvulla tapahtuneessa elinikäisen oppimisen transformaatiossa vapaan sivistystyön instituutiorakenteet on purettu, lainsäädännöllinen perustehtävä on muuttunut aiempaa valtio-ohjautuneemmaksi, aktiivinen tutkimustoiminta on paloiteltu osaksi kehittämishankkeita, ja vapaaseen sivistystyöhön erikoistuneiden aikuiskasvattajien pätevöityminen ja toimenkuvat on valjastettu sivistysjärjestelmässä uudenlaiseen käyttöön. Näyttää siltä, että vapaa sivistystyö on revitty palasiksi palvelemaan kansalaisyhteiskunnassa kulloinkin tärkeänä pidettyä tehtävää.

KANSALAISTIETEEN ESIINTULON taustalla vaikuttaa Teollisuus 4.0, neljäs teollinen vallankumous, joka on nostanut digitalisaation keinoksi osallistaa kansalaiset mukaan yhteiseen tiedon rakenteluun. Termi kuvaa kokonaisuutta, jonka esineiden internetiin pohjautuvat teknologiat, tekoäly, lisätty todellisuus, edistynyt analytiikka ja automaatio yhdessä muodostavat. Tärkein strateginen muutosajuri on globaali ilmastonmuutos, joka asettaa luonnontieteen tutkimuksen ja ihmisen elämän säilyttämisen maapallolla tutkimuksen keskiöön. Tässä keskustelussa myös aikuiskasvatustieteen tulisi olla mukana.

Esimerkki kansalaistieteen toimintatavoista on digitaalinen CS-Track-projekti, jossa on kehitetty CitieS-Health Toolkit havainnoimaan muutoksia ihmisen terveydessä. Sen tavoite on saada yhteisöt mukaan ratkaisemaan ongelmia ja toteuttamaan toimia, joilla maailmasta tulee parempi paikka elää. Työkalu pyrkii ohjaamaan ihmisiä tutkimaan ja määrittelemään omassa lähiyhteisössä vaikuttavia tärkeitä ympäristö- ja terveyskysymyksiä. Kansalaiset ohjataan tutkimuksen suunnitteluun ja ennakoivan tiedon keräämiseen. 
Digitaalisuus tempaa mukaansa myös nuoret ja hyödyntää pelillisyyttä: Verkkopohjaisen ongelmanratkaisupeli Folditin tavoite on saada aikaan paras mahdollinen kolmiulotteinen muoto proteiinille. Pitkäketjuiset proteiinit eivät muodosta suoraa ketjua vaan mukautuvat eli laskostuvat tiettyyn muotoon. Samanlainen proteiini laskostuu aina samanlaiseksi. Pelissä hyödynnetään ihmisen ongelmanratkaisukyvykkyyttä. Parhaat tulokset päätyvät tutkijoiden analysoitaviksi kansainvälisen Critical Assessment of Protein Structure Prediction (CASP) -liikkeen kautta.

Olisiko vastaavissa esimerkeissä ideaa vapaan sivistystyön ja aikuiskasvatustieteen monitieteiselle tutkimusohjelmalle? Ihmisen oppiminen ja kansalaiseksi kasvaminen muuttuvassa maailmassa pysyy tärkeänä tutkimuskohteena, joka olisi liitettävä mukaan tieteellisen tutkimuksen keskiöön.

HEIKKINEN JA PÄTÄRI KYSYVÄT, soveltuisiko kansalaistiede-puhe tieteenaloihin, joiden kohteena ovat kansalaisuus ja kansalaiseksi määrittely. Hallitseva kansalaistieteen tutkimusalue on ympäristötieteet. Toisaalta julkisen tiedepoliittisen keskustelun keskiössä on pandemiavuoden ajan ollut rokotetutkimus, jonka tieltä muut tieteenalat ovat väistyneet. Kansalaistiede voisi hyvin soveltua tukemaan aikuiskasvatustieteen tutkimusta.

Varhaisista sivistysteoreetikoista professori Zachris Castrénia (1924) mukaillen vapaa kansansivistystyö ja eri tieteenalat hyötyvät vastavuoroisesta yhteistyöstä. Hänen mukaansa tieteellisen tutkimuksen ja korkeamman opetuksen tuli asettua johtamaan kansansivistäjien työtä sivistyksellisen yhteiskunnan luomisessa, mikä puolestaan integroisi erikoistuneita ja hajaantuneita tieteitä ja rakentaisi niissä kokonaisnäkemystä. Kansalaistieteen digitaalisilla työkaluilla olisi mahdollista havainnoida elinikäistä oppimista kouluasteelta toiselle ja tutkia informaalin ja nonformaalin oppimisen kehitystä yhä tarkemmin. Olisiko näin mahdollista toteuttaa kenttätutkimus, jolla kerätään aineistoa maahanmuuttajaopiskelijan kokemuksista ja havainnoista kansalaisuuden muodostumisesta ja identiteetin rakentumisesta uudessa kulttuuriympäristössä? Aikuiskasvatustieteen tutkimusaihioiden ja -tarpeiden määrä kansalaistieteessä on käytännössä rajaton.
KANSALAISTIEDE TUO TIETEEN tekemisen lähelle niitä, joilla ei ole tutkijan koulutusta tai tutkimuksen vaatimia erityistaitoja. Kansalaiset voisivat edistää tutkimusta keräämällä uutta aineistoa ja syventämällä olemassa olevaa tietoa. Kansalaistieteessä on sama timanttinen idea kuin vapaassa sivistystyössä: voit sivistää itseäsi, lisätä tietoja ja taitoja ilman pohjakoulutusta tai pääsyvaatimuksia. Tärkeintä on, että olet kiinnostunut ja motivoitunut osallistumaan toimintaan yhdessä muiden kiinnostuneiden kanssa.

Lisäksi oppilaitosten opetuksen ja toiminnan digitaalistaminen suoltaa valtavan määrän Big Dataa, jota voisi systemaattisesti analysoida. Kuinka aikuiskasvatustieteen tutkimus voisi hyödyntää oppilaitosten opetusalustoille syntyvää massatietoa: kuinka, missä, milloin ja mitä eritaustaiset opiskelijat opiskelevat? Kuinka tätä tietoa voisi tieteellisesti tutkia ja analysoida aikuisten elinikäistä opetusta kehitettäessä?

Suuren yleisön luottamus tieteen tekijöitä ja instituutioita kohtaan rakentaa tieteen tekemiselle vankan kivijalan. Tästä on syytä pitää yhteisesti kiinni. Kansalaistieteen avoimuudella ja käytön leviämisellä on kuitenkin paljon etuja kaikille tieteenaloille. Ongelma voi olla pikemminkin se, että kun kansalaiset ovat yhä koulutetumpia, heidät on vaikea vakuuttaa kansalaistieteen merkityksestä.

Tiedebarometrin analyysi toteaa $(2019,96-97)$ : "Koulutetuimpien kannoissa on kuultavissa kaikuja jonkinasteisesta 'tietämättömät älkööt puuttuko' -mentaliteetista. Riippuvuudessa voi nähdä yhtymäkohtia kansanvaltaisuus- ja asiantuntemusnäkökohtien yleisempäänkin hankaukseen yhteiskunnallisessa päätöksenteossa. Vaikuttaa siltä, että tieteen tekijät haluavat pitää tutkimuksen omassa hallinnassaan, ja vain varauksella tarjota kansalaiselle mahdollisuuden tieteellisen tiedon kerääjäksi.”

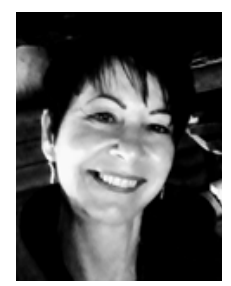

TARJA LANG

FT, tutkimuspäällikkö Omnia, Espoon seudun koulutuskuntayhtymä 


\section{LÄHTEET.}

Apo, S. (1998). Suomalaisuuden stigmatisoinnin tradition. Teoksessa P. Alasuutari \& P. Ruuska

(toim.) Elävänä Euroopassa. Muuttuva suomalainen identiteetti. Tampere: Vastapaino, 83-128.

Castrén, Z. (1924). Yliopisto ja vapaa kansansivistystyö. Kansanvalistus ja kirjastolehti, no 5, 217-228.

CitieS-Health`s Citizen Science toolkit. https://cstrack.eu/ news/cities-healths-citizen-science-toolkit

Jong, E. (2020). How science beat the virus. And what it lost in the process. The Atlantic, 14.12.2020. Saatavissa: https://www.theatlantic.com/magazine/ archive/2021/01/science-covid-19-manhattanproject/617262

Kirjavainen, T. \& Pulkkinen, J. (2017). Pisatulokset heikentyneet huippuvuosista - kuinka paljon ja mistä se voisi johtua? Jyväskylän yliopisto. Saatavissa: https://jyx. jyu.fi/bitstream/handle/123456789/55549/1/ ty32017kirjavainenpulkkinen.pdf

Koski, L. (2006). Kansansivistyksen kansaa etsimässä. Teoksessa J. Tuomisto \& P. Salo (toim.). Edistävä ja viihdyttävä aikuiskasvatus. Aulis Alanen aikuisopetuksen laatua etsimässä. Tampere: Tampere University Press.
Lang, T. (2011). Myyttisestä sankarirehtorista opistoäidiksi ja manageriksi. Sukupuolen näkökulma kansalais- ja työväenopiston johtajuuteen. Väitöskirja. Helsingin yliopisto.

Manske, S. (2020). What are the predominant research areas in citizen science projects? Projektissa CS Track. Investigating Citizen Science. https://cstrack.eu/ graphical-article/predominant-research-areas-citizenscience-projects

Miller, J. A., Khatib, F., Hammond, H., Cooper, S. \& Horowitz, S. (2020). Introducing Foldit Education Model. Nature Structural and Molecular Biology, 27, 769-770.

Ollila, A. (1993). Suomen kotien päivä valkenee... Marttajärjestö suomalaisessa yhteiskunnassa vuoteen 1939. Tampere: Suomen Historiallinen Seura.

Tiedebarometri 2019. (2020). Tieteen tiedotus ry. Yhdyskuntatutkimus Oy. Saatavissa: http://www. tieteentiedotus.fi/files/Tiedebarometri_2019.pdf

Tuomaala, S. (2004). Työtätekevistä käsistä puhtaiksi ja kirjoittaviksi. Suomalaisen oppivelvollisuuskoulun ja maalaislasten kohtaaminen 1921-1939. Helsinki: Suomalaisen Kirjallisuuden Seura. 